\title{
Coronatine and Abscission in Citrus
}

\author{
Jacqueline K. Burns, ${ }^{1}$ Luis V. Pozo, Covadonga R. Arias, and Brandon Hockema \\ Horticultural Sciences, University of Florida, Institute of Food and Agricultural Sciences, Citrus \\ Research and Education Center, 700 Experiment Station Road, Lake Alfred, FL 33850-2299
}

Vidhya Rangaswamy and Carol L. Bender

Department of Entomology and Plant Pathology, Oklahoma State University, Stillwater, OK 74078

\begin{abstract}
AdDitional InDEX wORDs. 5-chloro-3-methyl-4-nitro-pyrazole, chlorophyll, coronafacic acid, coronamic acid, ethephon, ethylene, methyl jasmonate, 12-oxo-phytodienoate, Pseudomonas syringae

Abstract. Coronatine is a polyketide phytotoxin produced by several plant pathogenic Pseudomonas spp. The effect of coronatine on abscission in Citrus sinensis L. Osbeck 'Hamlin' and 'Valencia' orange fruit, leaves, fruitlets, and flowers was determined. Coronatine at $200 \mathrm{mg} \cdot \mathrm{L}^{-1}$ significantly reduced fruit detachment force of mature fruit, and did not cause fruitlet or flower loss in 'Valencia'. Cumulative leaf loss was $18 \%$ with coronatine treatment. Coronafacic acid or coronamic acid, precursors to coronatine in Pseudomonas syringae, did not cause mature fruit abscission. Ethylene production in mature fruit and leaves was stimulated by coronatine treatment, and 1-aminocyclopropane-1-carboxylic acid oxidase (ACO) and 12-oxo-phytodienoate reductase (12-oxo-PDAR) gene expression was upregulated. A slight chlorosis developed in the canopy of whole trees sprayed with coronatine, and chlorophyll content was reduced relative to adjuvant-treated controls. Leaves formed after coronatine application were not chlorotic and had chlorophyll contents similar to controls. Comparison of coronatine to the abscission compounds methyl jasmonate, 5-chloro-3methyl-4-nitro-pyrazole and ethephon indicated differences in ethylene production and ACO and 12-oxo-PDAR gene expression between treatments. Leaf loss, chlorophyll reduction and low coronatine yield during fermentation must be overcome for coronatine to be seriously considered as an abscission material for citrus.
\end{abstract}

Coronatine is a polyketide phytotoxin produced by several plant pathogenic Pseudomonas spp. (Mitchell 1982; Völksch and Weingart 1998). In compatible host-pathogen interactions, coronatine was associated with virulence and symptom development. Coronatine induces a diffuse nonhost-specific chlorosis after application to many plants (Bender et al. 1999; Gnanamanickam et al., 1982; Mitchell and Young, 1978). Although the mode of action of coronatine is not known, recent work demonstrated that coronatine was immunolocalized to the chloroplast and induced proteinase inhibitor and chlorophyllase gene expression (Tsuchiya et al., 1999; Zhao et al., 2001). In addition to its phytotoxic effects, coronatine can also induce growth regulator-like effects such as hypertrophy and can stimulate ethylene production and tendril coiling (Ferguson and Mitchell, 1985; Gnanamanickam et al., 1982; Kenyon and Turner, 1992; Perner et al., 1994; Stelmach et al., 1999).

It has been reported that coronatine shares significant structural and functional similarities with jasmonic acid, its precursor 12oxophytodienoate, and methyl jasmonate, which are plant growth substances important in octadecanoid signaling (Haider et al., 2000; Koch et al, 1999; Koda et al., 1996; Weiler et al., 1994). Components of the octadecanoid pathway have been shown to affect the regulation of defense responses (Penninckx et al., 1998; Rickauer et al., 1997), wounding (Benedetti et al., 1998), fruit ripening (Fan et al., 1998), and abscission (Miyamoto et al., 1997; Ueda et al., 1996). Our interest in octadecanoid compounds was in their potential as abscission-inducing agents for citrus. Both jasmonic acid and its methyl ester methyl jasmonate

Reveiced for publication 8 Jan. 2003. Acepted for publication 28 Feb. 2003. The authors wish to thank Anna Redondo and Aswathy Raghavan for excellent technical assistance. This research was supported by the Florida Agricultural Experiment Station, theInstitute of Food and Agricultural Sciences, University of Florida, andgrants from the Florida Department of Citrus (01-31) to J.K.B, the Oklahoma Center for Advancement of Science and Technology \#AR031-005, and the National Science Foundation IBN-0130693 (C.L.B), and approved for publication as journal series R-09059.

${ }^{1}$ Corresponding author; e-mail jkbu@lal.ufl.edu. were shown to induce leaf abscission in bean explants without significant production of ethylene (Miyamoto et al., 1997; Ueda et al., 1996). In citrus, methyl jasmonate induced citrus mature fruit abscission when applied to the entire tree canopy (Hartmond et al., 2000a; Kender et al., 2001). However, unacceptable leaf abscission occurred in 'Valencia' orange, and this was associated with increased ethylene production in both leaves and fruit. Since coronatine and octadecanoid compounds can induce similar biological activities, we tested the ability of coronatine to cause abscission in citrus. Overall, our results indicate that coronatine induced mature fruit abscission, had low leaf loss, and did not cause immature fruit or flower loss.

\section{Materials and Methods}

BACTERIAL STRAINS AND GROWTH CONDITIONS. For all experiments described in this work we used Pseudomonas syringae pv. glycinea PG4180.N9 to produce coronatine. Pseudomonas syringae pv. glycinea PG4180.C0 and PG4180.B2 were used to produce the precursors to coronatine, coronafacic acid (CFA), and coronamic acid (CMA), respectively (Ullrich et al., 1994). Cells were routinely cultured on mannitol-glutamate-yeast extract medium (MGY; Keane et al., 1970) at $26^{\circ} \mathrm{C}$. For coronatine production, a previously described two-step fermentation protocol was used (Palmer and Bender, 1993). Briefly, for each fermentation batch, a loop of fresh culture was inoculated into 12 different tubes containing $10 \mathrm{~mL}$ MGY broth supplemented with $10 \mu \mathrm{g} \cdot \mathrm{mL}^{-1}$ of kanamycin. Starter tubes were incubated in a rotary shaker at 26 ${ }^{\circ} \mathrm{C}$ and $220 \mathrm{rpm}$. After $48 \mathrm{~h}$, cultures obtained a density of $\approx 1.0 \times$ $10^{7} \mathrm{cfu} / \mathrm{mL}\left(\mathrm{A}_{600} 1.0\right)$. All starter cultures were combined and 25 $\mathrm{mL}$ were inoculated into 1-L baffled flasks containing $475 \mathrm{~mL}$ of Hoitink-Sinden medium (Palmer and Bender, 1993) supplemented with $10 \mu \mathrm{g} \cdot \mathrm{mL}^{-1} \mathrm{kanamycin}$. Fermentation was carried out at 18 ${ }^{\circ} \mathrm{C}$ for $6 \mathrm{~d}$ at $220 \mathrm{rpm}$ in a rotary shaker.

ISOLATION AND QUANTITATION OF CORONATINE. Coronatine was isolated from the fermentation media by partitioning against ethyl 
acetate and sodium carbonate as described by Palmer and Bender (1993). After drying in vacuo, coronatine was stored at $-80{ }^{\circ} \mathrm{C}$. Before application, the material was quantified by HPLC as described (Palmer and Bender, 1993).

Plant material. Citrus sinensis (L.) Osb. 'Hamlin' or 'Valencia' grown at the Citrus Research and Education Center, Lake Alfred, Fla., was used. Studies were conducted in the 1999, 2000, 2001, and 2002 seasons. Experiments with 'Hamlin' oranges were conducted in November, December, or January, whereas experiments with 'Valencia' oranges were conducted in March, April, May, or June. Average minimum and maximum temperatures during experiments with 'Hamlin' were 11.3 and $23.6^{\circ} \mathrm{C}$, respectively, and 18.6 and $34.1^{\circ} \mathrm{C}$, respectively, with 'Valencia'. No rain fell on trees within the first $3 \mathrm{~d}$ after application. Trees on 'Swingle' rootstock were 12 to 16 years of age and ranged from 3 to $5 \mathrm{~m}$ in height. In most experiments, coronatine or other abscission compounds were applied to isolated branches. Branch sprays consisted of five branches on each of three trees, with at least 10 fruit and 50 leaves per branch. Branch tests were replicated at least three times. Loss of 60-d-old fruitlets was evaluated in 'Valencia' orange using branch tests as described above. In one experiment conducted in 2002, coronatine was applied to entire trees. In this case, four trees of 'Valencia' orange were used. Three replicates of mature and young leaves (12 leaves/replication) were randomly removed from two trees at the north, south, east, and west canopy locations for chlorophyll analysis.

Abscission materials AND APPlication to Citrus. Ethephon (Aventis, Ethrel, [2-chloroethyl] phosphonic acid), Ally (Dupont Chemical, metsulfuron-methyl, methyl2-[([([(4-methoxy-6-methyl-1,3,5-triazin-2yl) amino] carbonyl) amino] sulfonyl) benzoate] and Kinetic adjuvant (Setre Chemical Co., Memphis, Tenn.) were purchased from Helena Chemical Company (Collierville, Tenn.). 5-Chloro-3-methyl-4-nitro-pyrazole(CMN-P; $17.18 \%$ active ingredient) was applied as formulated by Abbott Laboratories $\approx 30$ years ago (Wilson et al., 1973). Methyl jasmonate (MJ) was purchased from Bedoukian Research Inc. (Danbury, Conn.). Coronatine, CFA or CMA were extracted from the fermentation media and quantified by HPLC as described by Palmer and Bender (1993).

Abscission materials were dispersed in $0.125 \%$ Kinetic immediately before application to the citrus canopy. Ethephon and CMN-P were applied at $200 \mathrm{mg}$ active ingredient/L. Metsulfuronmethyl was applied at $2 \mathrm{mg}$ active ingredient/L. Coronatine was applied at concentrations ranging from 0 to $300 \mathrm{mg} \cdot \mathrm{L}^{-1}$; whereas CFA and CMA were applied at $100 \mathrm{mg} \cdot \mathrm{L}^{-1}$. Treatments were applied to citrus until solutions began to run-off the canopy.

Measurements. Fruit detachment force (FDF) in $\mathrm{kg}$ was measured within $5 \mathrm{~d}$ after application of ethephon, coronatine, CFA, CMA or CMN-P and $10 \mathrm{~d}$ after application of metsulfuronmethyl using a Force Five pull-force gauge (Wagner Instruments, Greenwich, Conn.) as described (Hartmond et al., 2000b). Leaf loss in ethephon and coronatine treatments was measured $10 \mathrm{~d}$ after application of coronatine or ethephon. Leaf loss was expressed as a percentage by counting the total number of leaves at the beginning of each test and dividing by the number of leaves dropped. Fruitlet loss with coronatine, metsulfuron-methyl or CMN-P treatments was determined $22 \mathrm{~d}$ after application and expressed as percentage as described above. Chlorophyll was extracted from leaves of 'Valencia' and quantified according to the method outlined by Hipkins and Baker (1986). Analysis of variance and Duncan's multiple range test were performed using the SAS statistical package (SAS Inst. Inc., Cary, N.C.). Ethylene production from mature fruit and leaves of 'Hamlin' orange was measured by gas chromatography as described by Burns et al. (1999). Data were presented as means \pm SE mean.

GENE EXPRESSION ANALYSIS. Total RNA was extracted from fruit abscission zones, leaf abscission zones, and leaf blades of Citrus sinensis 'Hamlin' orange $24 \mathrm{~h}$ after application of coronatine, CMN-P, ethephon, $10 \mathrm{~mm} \mathrm{MJ}$, or adjuvant (Burns et al. 1998). Ten micrograms of total RNA were electrophoresed on a $1 \%$ formaldehyde-agarose gel and transferred to Hybond-N membranes (Amersham, Pharmacia, Biotech Inc., Piscataway, N.J.) by capillarity using $10 \times \mathrm{SSC}$ as transfer buffer. Membranes were dried, cross-linked, and prehybridized in Perfect Hyb Plus hybridization buffer (Sigma Chemical Co., St. Louis, Mo.). RNA was hybridized with digoxigenin labeled cDNA probes (DIG Prime DNA Labeling and Detection Starter Kit II, Roche, Indianapolis, Ind.) following the manufacturer's instructions. Probes were generated using partial cDNAs sequences of ACO and 12-oxo PDAR genes previously isolated from citrus (Burns, 2002). Sequences were cloned into pGEMT-easy (Promega, Madison, Wis.) and used as DNA templates for PCR reactions. PCR amplification was performed with primers derived from the vector which flanked the insert DNA. PCR conditions were: initial denaturing at 94 ${ }^{\circ} \mathrm{C}$ for $5 \mathrm{~min}$; 35 cycles denaturing at $94{ }^{\circ} \mathrm{C}$ for $1 \mathrm{~min}$, annealing at $55^{\circ} \mathrm{C}$ for $1 \mathrm{~min}$ and extension at $72^{\circ} \mathrm{C}$ for $2 \mathrm{~min}$, with a final extension step of $10 \mathrm{~min}$ at $72^{\circ} \mathrm{C}$. Hybridization signals were quantified using Quantity One Quantitation Software (Bio-Rad, Hercules, Calif.). Gene expression analysis was repeated twice with total RNA from each treatment.

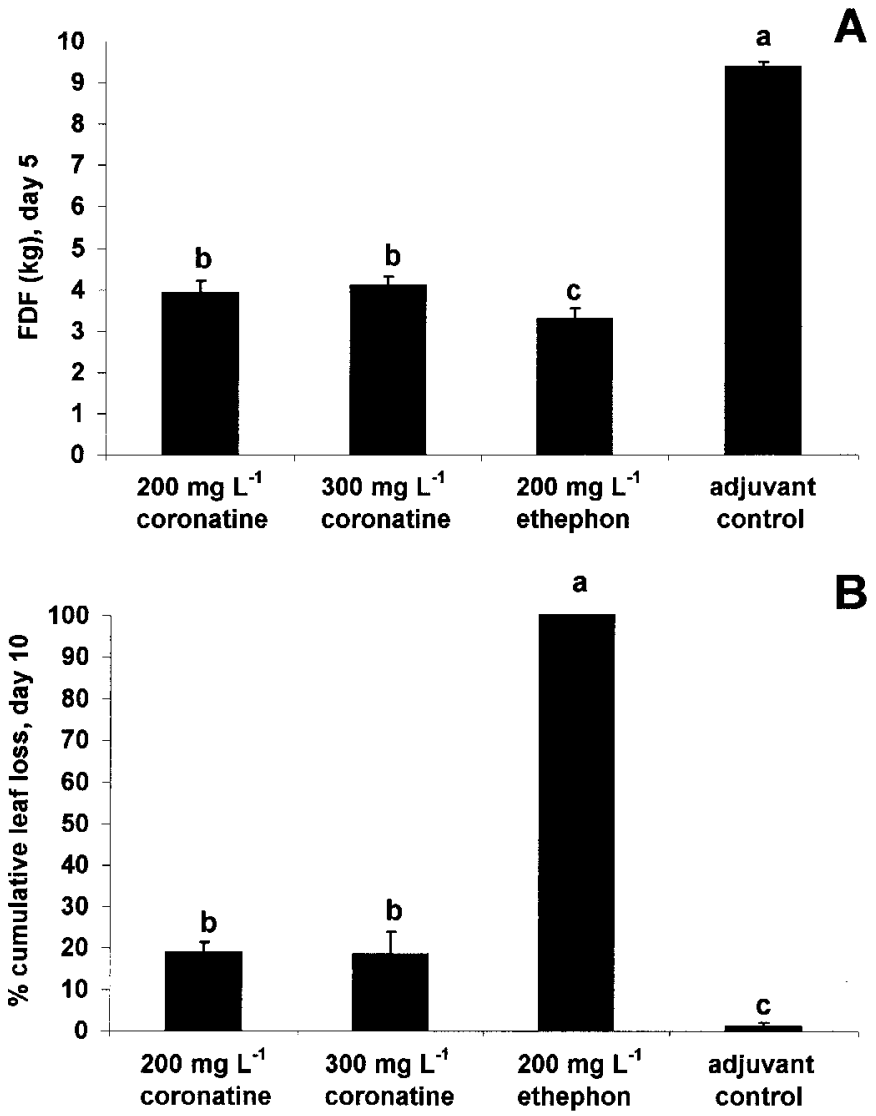

Fig. 1. The effect of coronatine on fruit detachment force (FDF) (A) and $\%$ cumulative leaf drop $(\mathbf{B})$ in 'Hamlin' orange branch tests. Coronatine was applied at 200 and $300 \mathrm{mg} \cdot \mathrm{L}^{-1}$, ethephon at $200 \mathrm{mg} \cdot \mathrm{L}^{-1}$ and Kinetic adjuvant alone at $0.125 \%$. Vertical bars represent SE mean. Mean separation by Duncan's multiple range test, $P<0.05$. 


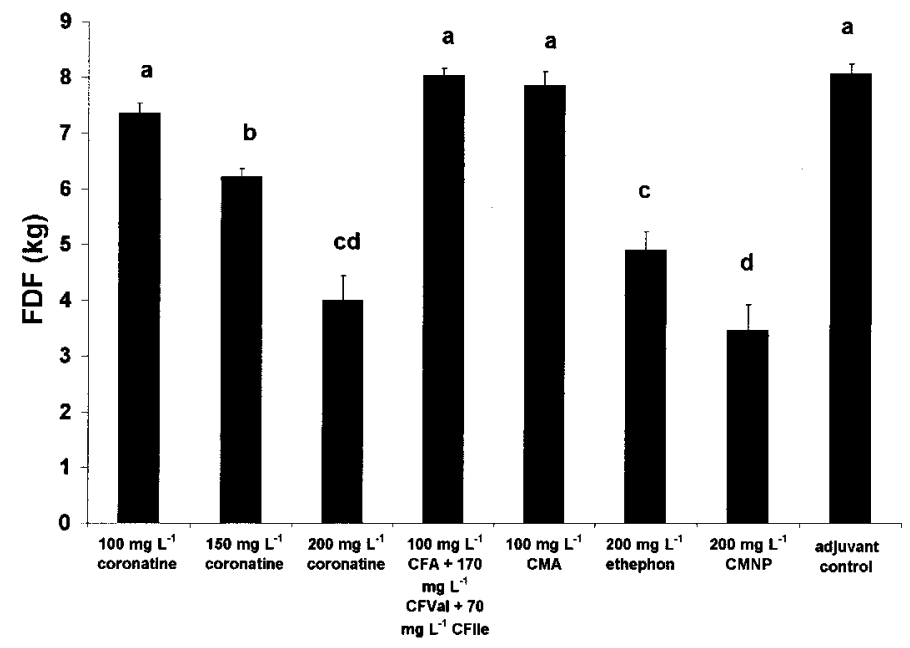

Fig. 2. The effect of various coronatine concentrations on fruit detachment force (FDF) in 'Valencia' orange branch tests. Coronafacic acid (CFA; including $170 \mathrm{mg} \cdot \mathrm{L}^{-1} \mathrm{CFVal}+70 \mathrm{mg} \cdot \mathrm{L}^{-1} \mathrm{CFIle}$ ) and coronamic acid (CMA) at $100 \mathrm{mg} \cdot \mathrm{L}^{-1}$ were also included in the trial. Coronatine and coronatine precursors were compared with $200 \mathrm{mg} \cdot \mathrm{L}^{-1}$ ethephon, 200 $\mathrm{mg} \cdot \mathrm{L}^{-1} \mathrm{CMN}-\mathrm{Por}$ Kinetic adjuvantalone at $0.125 \%$. Vertical bars represent SE mean. Mean separation by Duncan's multiple range test, $P<0.05$.

\section{Results}

Coronatine reduced FDF in 'Hamlin' orange when applied at 200 and $300 \mathrm{mg} \cdot \mathrm{L}^{-1}$ to branches (Fig. 1A). A similar reduction in FDF was measured in fruit treated with $200 \mathrm{mg} \cdot \mathrm{L}^{-1}$ ethephon.
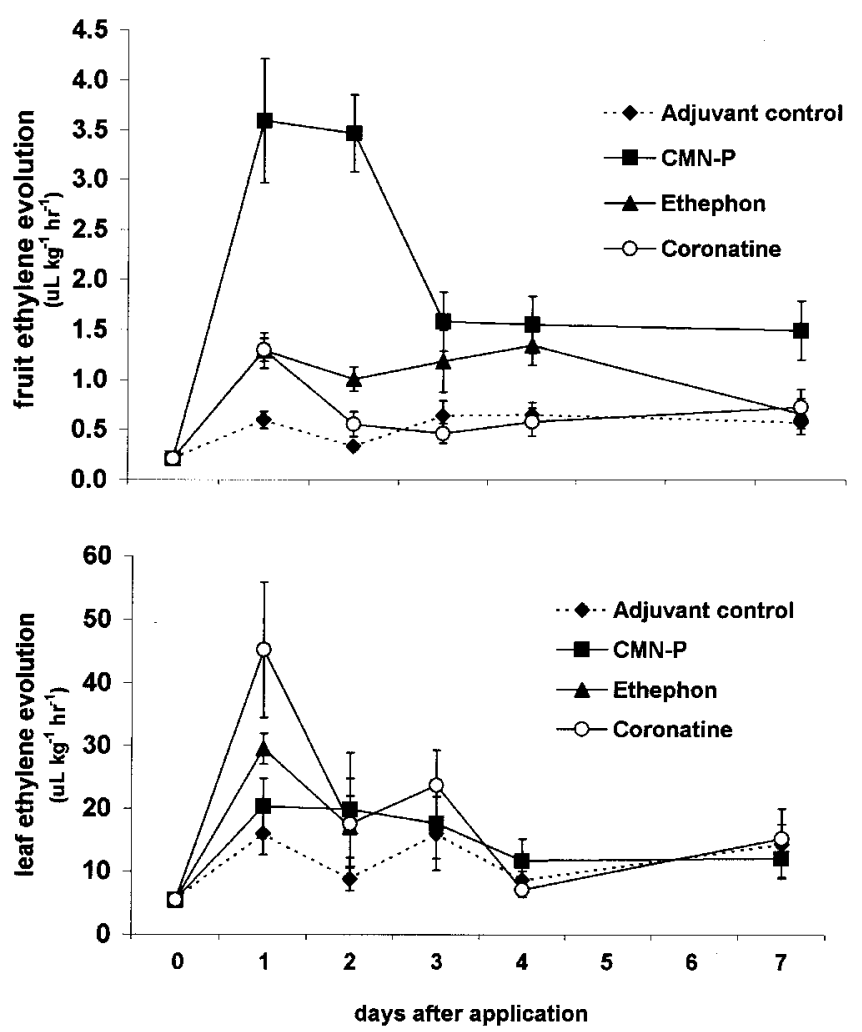

Fig. 3. Ethylene evolution in 'Hamlin' mature fruit (A) and leaves (B) after treatment with $200 \mathrm{mg} \cdot \mathrm{L}^{-1}$ coronatine, $200 \mathrm{mg} \cdot \mathrm{L}^{-1}$ ethephon, 200 $\mathrm{mg} \cdot \mathrm{L}^{-1} \mathrm{CMN}-\mathrm{P}$ or Kinetic adjuvant alone at $0.125 \%$. Vertical bars represent SE mean.

A
Coronatine caused $18 \%$ leaf loss when applied at both concentrations (Fig. 1B). Leaf loss was unacceptably high with ethephon and was $100 \% 10 \mathrm{~d}$ after application.

In branch tests with 'Valencia' orange, coronatine concentrations below $200 \mathrm{mg} \cdot \mathrm{L}^{-1}$ only slightly reduced FDF, whereas 200 $\mathrm{mg} \cdot \mathrm{L}^{-1}$ coronatine was as effective as $200 \mathrm{mg} \cdot \mathrm{L}^{-1}$ ethephon or CMN-P (Fig. 2), an abscission material specific for mature citrus fruit (Burns, 2002). Coronatine precursors were applied to 'Valencia' orange to determine if these compounds could induce mature fruit abscission. Pseudomonas syringae pv. glycinea PG4180.C0 strain produces CFA during fermentation, but also produces the coronafacoyl analogs coronafacoylvaline (CFVal) and coronafacoylisoleucine (CFIle) (Young, et al., 1992). Application of

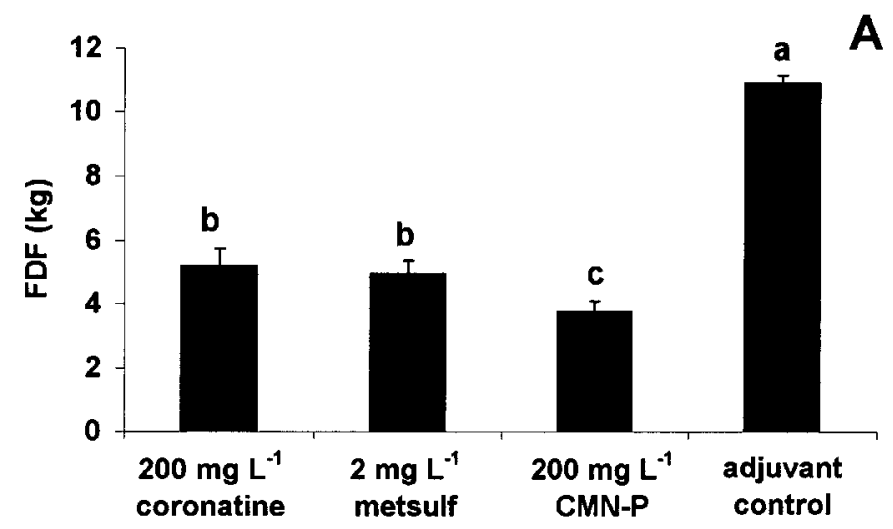

no 18

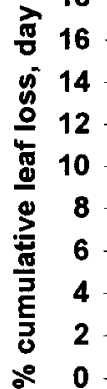

a

$\mathbf{B}$

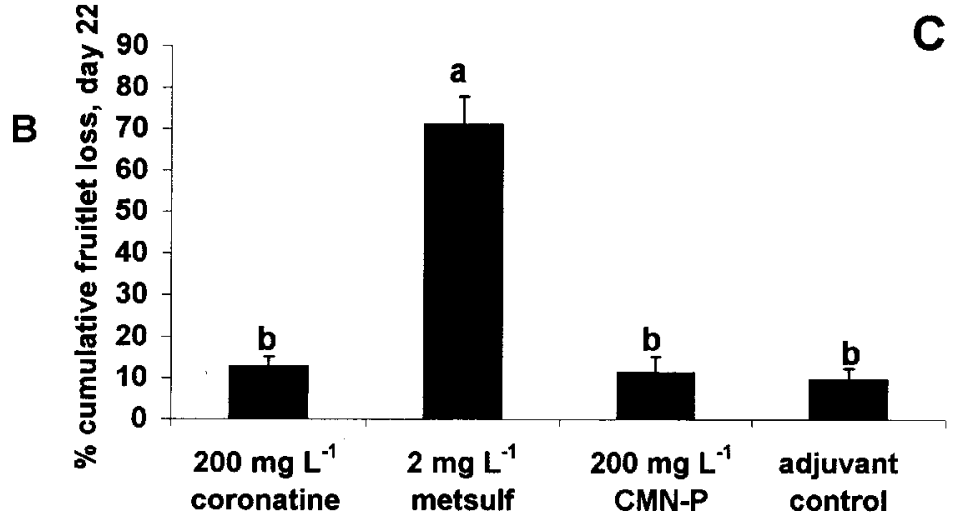

Fig. 4. The effect of whole tree application of $200 \mathrm{mg} \cdot \mathrm{L}^{-1}$ coronatine, 2 $\mathrm{mg} \cdot \mathrm{L}^{-1}$ metsulfuron-methyl (metsulf), $200 \mathrm{mg} \cdot \mathrm{L}^{-1} \mathrm{CMN}-\mathrm{P}$ and Kinetic adjuvant alone at $0.125 \%$ on fruit detachment force (FDF) (A), \% cumulative leaf loss $(\mathbf{B})$, and \% cumulative fruitlet loss $(\mathbf{C})$ in 'Valencia' orange. FDF was measured $10 \mathrm{~d}$ after metsulf application and $5 \mathrm{~d}$ after application of other treatments. Vertical bars represent SE mean. Mean separation by Duncan's multiple range test, $P<0.05$. 

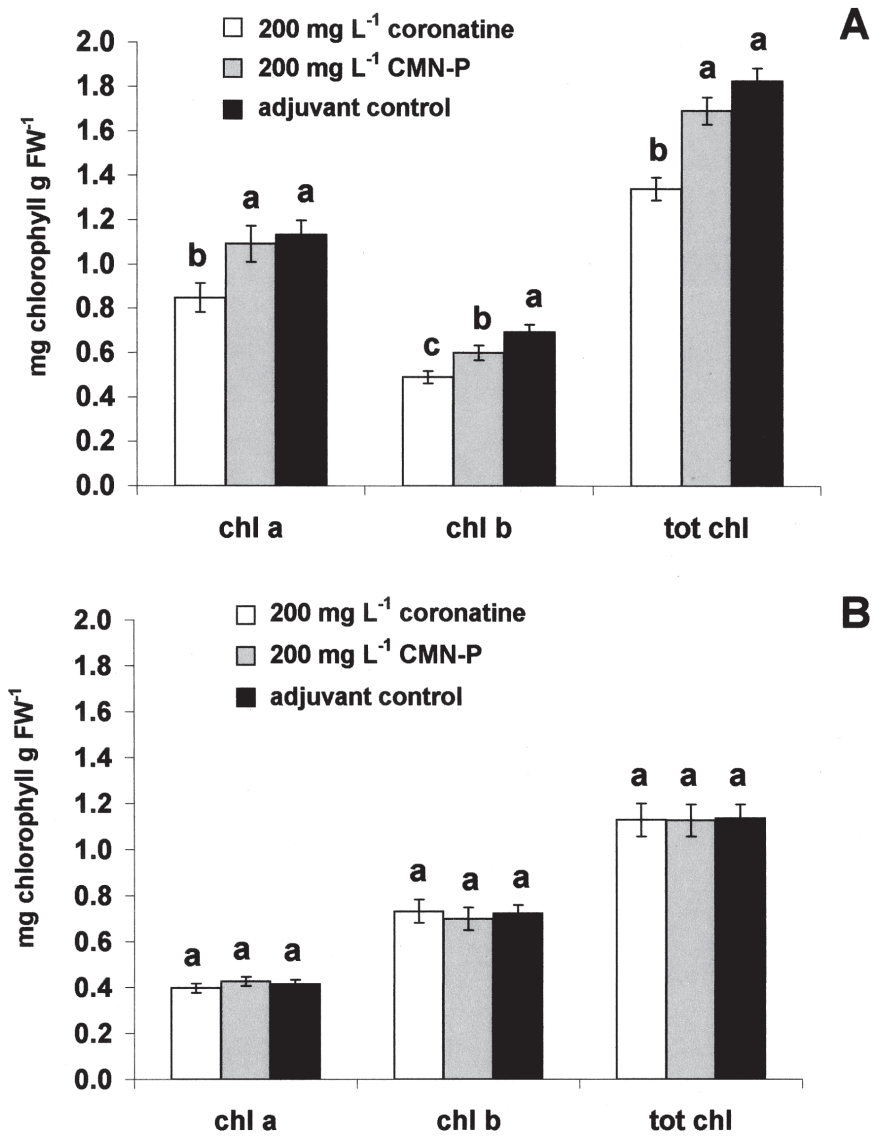

Fig. 5. Chlorophyll a (chl a), chlorophyll b (chl b) and total chlorophyll (total chl) content $60 \mathrm{~d}$ after whole tree application of $200 \mathrm{mg} \cdot \mathrm{L}^{-1}$ coronatine, $200 \mathrm{mg} \cdot \mathrm{L}^{-1} \mathrm{CMN}-\mathrm{P}$ and Kinetic adjuvant alone at $0.125 \%$ to 'Valencia' orange. (A) Mature leaves treated with abscission materials, (B) young leaves that developed $\approx 30 \mathrm{~d}$ after abscission material application. Vertical bars represent SE mean. Mean separation by Duncan's multiple range test, $P<0.05$. Means within each chlorophyll group followed by the same letter are not significantly different.

ethephon-treated fruit remained high for $5 \mathrm{~d}$ but was reduced thereafter. Coronatine induced high levels of ethylene in leaves $1 \mathrm{~d}$ after application and then decreased (Fig. 3B). Ethephon also induced high levels of ethylene, but levels were lower than the coronatine-treated plants. Two days after application of ethephon, all leaves abscised. In general, CMN-P and adjuvant control leaves had low but variable ethylene production.

Whole trees of 'Valencia' orange were sprayed with $200 \mathrm{mg} \cdot \mathrm{L}^{-1}$ coronatine, $2 \mathrm{mg} \cdot \mathrm{L}^{-1}$ metsulfuron-methyl, $200 \mathrm{mg} \cdot \mathrm{L}^{-1} \mathrm{CMN}-\mathrm{P}$, or adjuvant alone. FDF was reduced significantly with all abscission compound treatments, but leaf loss was higher with coronatine and metsulfuron-methyl (Fig. 4A and B). Leaf loss approached $70 \%$ with metsulfuron-methyl treatment $22 \mathrm{~d}$ after application but remained unchanged in the coronatine or CMN-P treatments (data not shown). Fruitlet loss was markedly higher with metsulfuronmethyl (Fig. 4C). However, fruitlet loss was low in coronatine and CMN-P treatments and no different than the adjuvant control. Flower abscission was also unaffected by coronatine (data not shown). Unlike branch applications of coronatine, a slight chlorosis developed in the canopy beginning about one week after
$100 \mathrm{mg} \cdot \mathrm{L}^{-1} \mathrm{CFA}$ solutions containing 170 and $70 \mathrm{mg} \cdot \mathrm{L}^{-1} \mathrm{CFV}$ al and CFIle, respectively, had no effect on FDF. Similarly, $100 \mathrm{mg} \cdot \mathrm{L}^{-1} \mathrm{CMA}$ had no effect on FDF.

Ethylene production was measured in mature fruit and leaves of 'Hamlin' branches treated with coronatine, ethephon, CMN-P and adjuvant alone. CMN-P increased ethylene production in mature fruit one day after application and was significantly greater than the other treatments (Fig. 3A). After 3 d, ethylene production dropped $\approx 50 \%$. Ethephon and coronatine also increased ethylene production one day after application. Coronatine-induced ethylene production decreased after the first day and remained low throughout the 7-d monitoring period. Ethylene production in

Fig. 6. ACC oxidase (A, B, and $\mathbf{C})$ and 12-oxo phytodienoate reductase $(\mathbf{D}, \mathbf{E}$, and $\mathbf{F})$ gene expression analysis of 'Hamlin' mature fruit abscission zones (A and $\mathbf{D}$ ), leaf abscission zones ( $\mathbf{B}$ and $\mathbf{E})$ and leaf blades $(\mathbf{C}$ and $\mathbf{F}) 24$ $\mathrm{h}$ after application of $200 \mathrm{mg} \cdot \mathrm{L}^{-1}$ coronatine (cor), $200 \mathrm{mg} \cdot \mathrm{L}^{-1} \mathrm{CMN}-\mathrm{P}, 10 \mathrm{~mm} \mathrm{MJ}, 200$ $\mathrm{mg} \cdot \mathrm{L}^{-1}$ ethephon (eth) and Kinetic adjuvant alone (control) at $0.125 \%$. Figure depicts a representative northern hybridization. In each panel, the top portion contains the image of the northern blot, the middle section contains the image of the ethidium bromide gel, and the lower graph depicts the relative gene expression within the northern blot.
ACC Oxidase
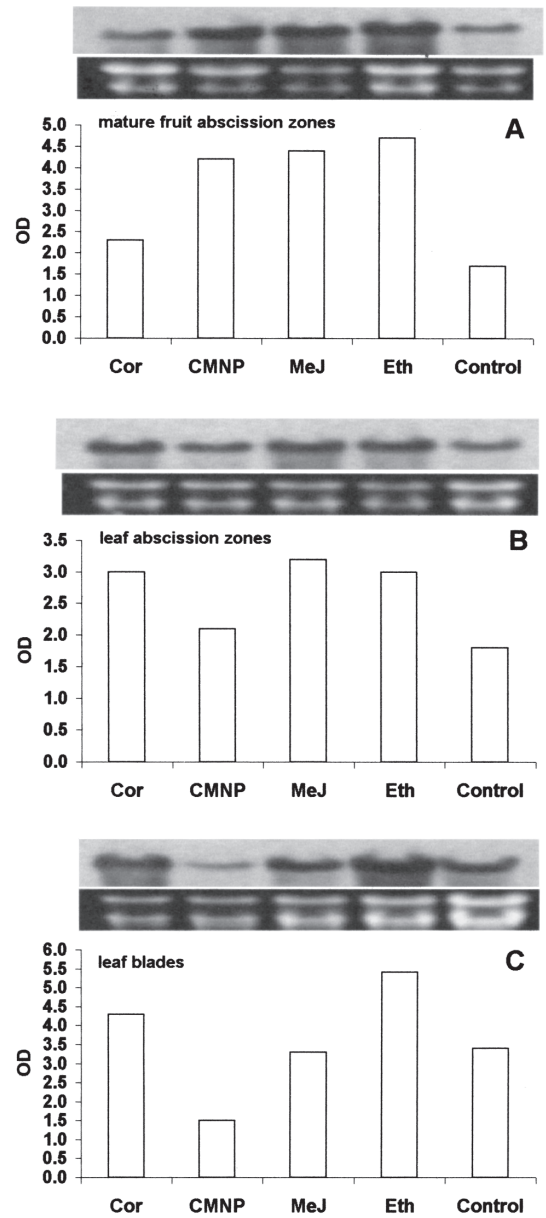

12-oxo Phytodienoate Reductase
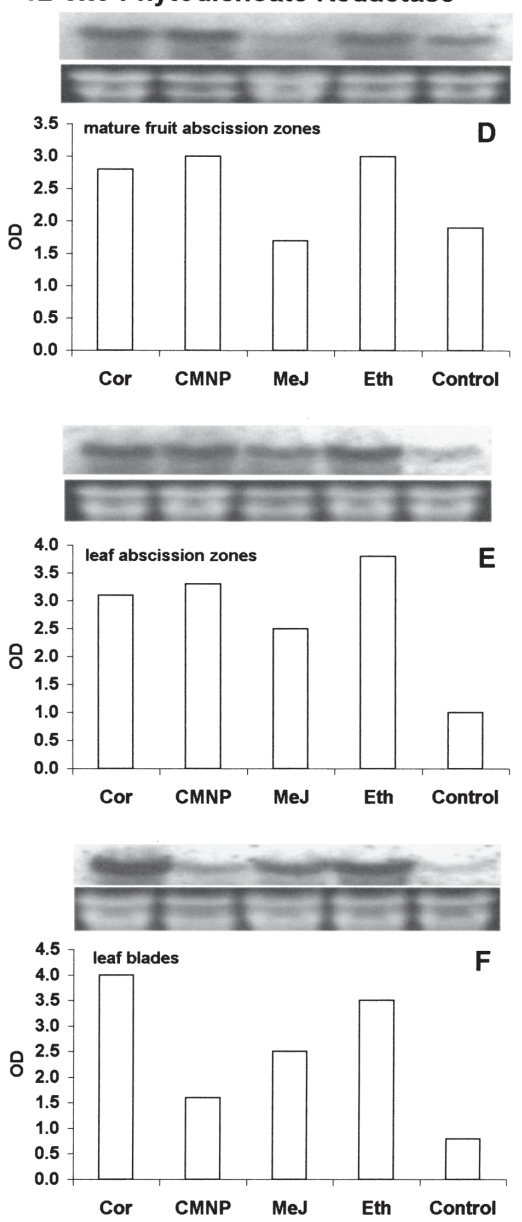
application to whole trees. After $60 \mathrm{~d}$, chlorophyll content was measured in leaves of trees treated with coronatine, CMN-P and adjuvant. Chlorophyll a, chlorophyll b, and total chlorophyll were reduced in leaves of coronatine-treated whole trees (Fig. 5A). However, leaves that emerged after coronatine application had chlorophyll content similar to leaves that emerged after treatment with CMN-P or adjuvant alone (Fig. 5B).

ACO and 12-oxo PDAR gene expression was monitored 24 $\mathrm{h}$ after application of abscission compounds. ACO was constitutively expressed in mature fruit abscission zones, leaf abscission zones, and leaf blades (control lanes in Fig. 6A, B, and C). A slight increase in ACO gene expression was measured with coronatine treatment in fruit abscission zones when compared with the adjuvant control (Fig. 6A). MJ, CMN-P and ethephon induced a 2-fold or greater increase in ACO gene expression in fruit abscission zones. ACO gene expression in leaf abscission zones was similar in CMN-P and adjuvant treatments, and was highest in leaves treated with other abscission compounds (Fig. 6B). ACO gene expression was suppressed in leaf blades treated with CMN-P but was elevated in leaf blades recovered from the coronatine and ethephon treatments. No change in ACO gene expression was measured with MJ-treated leaf blades as compared with adjuvant control. 12-Oxo PDAR gene expression was increased in mature fruit abscission zones, leaf abscission zones, and leaf blades treated with coronatine and ethephon (Figs. 6D, $\mathrm{E}$, and F). CMN-P increased 12-oxo PDA expression in fruit and leaf abscission zones but not in leafblades, whereas $\mathrm{MJ}$ increased expression in leaf abscission zones and leaf blades but not in fruit abscission zones.

\section{Discussion}

The biological activities of coronatine are similar to those of the oxylipins MJ, jasmonic acid, and 12-oxophytodienoate. These activities include the promotion of tuberization and cell expansion in potato, mechanotransduction, senescence, volatile synthesis, and induction of defense and wound related genes and their protein products (Falkenstein et al., 1991; Koch et al., 1999; Koda et al., 1996; Stelmach et al; 1998; Weiler et al., 1994). Jasmonic acid and MJ caused abscission in leaves and explants of bean (Miyamoto et al., 1997; Ueda et al., 1996) and citrus (Hartmond et al., 2000a; Kender et al., 2001). In this paper, we demonstrate that coronatine induced abscission in citrus. Applications of 200 $\mathrm{mg} \cdot \mathrm{L}^{-1}$ appeared to be optimal for mature citrus fruit loosening, as higher concentrations did not enhance the effect, and lower concentrations were not as efficacious. Mature fruit were particularly responsive to coronatine, whereas leaves were less responsive. This pattern of response was consistent throughout the harvest season in multiple years. Fruitlets and flowers did not abscise at the concentrations of coronatine tested. Similar results were obtained when MJ was used as a citrus abscission agent (Hartmond et al., 2000a). However, the response of 'Valencia' to MJ was much reduced and a higher concentration was needed to cause acceptable fruit loosening. Unfortunately, higher concentrations of MJ resulted in higher leaf loss. Although we noticed a slight reduction in efficacy later in the 'Valencia' harvest season, 200 $\mathrm{mg} \cdot \mathrm{L}^{-1}$ coronatine consistently reduced FDF to $>50 \%$ of its starting value. This value has been reported as a threshold FDF value for improving the harvesting efficiency of several mechanical harvesting technologies (Wilson, 1973).

Coronatine is composed of two distinct moieties: the polyketide CFA, and CMA, an ethylcyclopropyl derivative of isoleucine
(Bender et al., 1999). In some cases, CFA and CMA have been shown to exhibit biological activities. CMA is structurally similar to the ethylene precursor, aminocyclopropyl carboxylic acid (ACC). Addition of CMA to cut carnation flowers inhibited ethylene production and extended shelf life (Toshima et al., 1993), possibly because CMA may bind competitively to ACO, the enzyme responsible for the conversion of ACC to ethylene. $\mathrm{CFA}$, coronatine and $\mathrm{MJ}$ induced the production of proteinase inhibitors in tomato, but only coronatine caused chlorosis and changes in chloroplast structure (Palmer and Bender, 1995). Neither CMA nor CFA caused abscission in mature fruit at the concentrations tested.

The production of ethylene in mature citrus fruit and leaves was increased by the application of coronatine and was associated with abscission. Coronatine also induced ethylene production in leaves of bean (Ferguson and Mitchell, 1985), tobacco (Kenyon and Turner, 1992), and cell suspension cultures of Lycopersicon esculentum but not L. peruvianum (Perner et al., 1994). Although fruit treated with coronatine, CMN-P, MJ, or ethephon caused similar reductions in FDF, the amount of ethylene produced differed in fruit between treatments. ACO gene expression was induced by coronatine treatment in citrus leaf blades, leaf abscission zones, and to a lesser extent in mature fruit abscission zones. The elevated expression of ACO in leaf abscission zones was correlated with a significant increase in leaf drop. 12-Oxo PDAR gene expression was also monitored in the same tissues. The 12-oxo PDAR gene that was used to probe northern blots encoded a protein with high similarity to OPR2, a 12-oxo PDAR induced by wounding and stress (Biesgen and Weiler, 1999) but not significantly involved in jasmonic acid biosynthesis (Schaller et al., 2000). Three isozymes of 12-oxo PDAR have been identified in Arabidopsis thaliana, and these differ in substrate specificity and are differentially regulated (Biesgen and Weiler, 1999; Schaller et al., 2000). No information has appeared on the isolation, characterization or regulation of 12-oxo PDAR genes of citrus before our work. Coronatine induced 12-oxo PDAR expression in all tissues examined, with the highest induction in leaf tissues, suggesting that the application of coronatine imposed a general physiological stress. CMN-P induced marked 12-oxo PDAR expression in leaf abscission zones, although its effect on leaf abscission was minimal. In most cases, differences in ACO and 12-oxo PDAR gene expression were not great. However, unlike coronatine, MJ did not induce ACO gene expression in leaf blades and 12-oxo PDAR gene expression in mature fruit abscission zones above the levels observed in adjuvant-treated controls. Such differences in gene expression induced by oxylipins have been reported (Kramell et al., 2000) and may be the result of concentration and duration of application, as well as specificity of the compound for certain tissues.

Taken together, the results of these studies suggest that members of the octadecancoid signaling pathway can induce abscission, and their application can increase ethylene production in citrus. The jasmonic acid precursor, 12-oxo-PDA, has been shown to have similar biological activities to methyl jasmonate and jasmonic acid (Stelmach et al., 1998, 1999). However, some studies suggest that endogenous levels of 12-oxo PDA may be more important than jasmonic acid in regulating physiological processes (Parchmann et al., 1997). In separate studies,12-oxo PDA prepared either as an aqueous suspension with Kinetic or dissolved in DMSO and applied to 'Valencia' or 'Hamlin' at concentrations up to 245 $\mathrm{mg} \cdot \mathrm{L}^{-1}$ failed to reduce FDF (data not shown). Thus, it appears that coronatine and methyl jasmonate, but not 12-oxo-PDA, share 
a common signaling pathway that ultimately leads to abscission. However, the lack of response with 12-oxo-PDA may be caused by reduced uptake. Higher concentrations of 12-oxo-PDA should be applied with several different solvents to determine its ability to induce abscission.

The potential of coronatine as an abscission agent for citrus remains under evaluation. To be seriously considered as a viable abscission agent, several concerns must be addressed. Not surprisingly, whole tree application of coronatine caused a diffuse chlorosis in canopy leaves, which was supported by a concomitant reduction in chlorophyll. Shoots that emerged 4 weeks after coronatine application had chlorophyll contents similar to controls, suggesting that the chlorotic effect was limited to leaves initially contacted by the material. Furthermore, coronatine typically caused $15 \%$ to $20 \%$ leaf loss after application. Considering the number of active abscission materials and the range of defoliation levels in our screening trials, this amount of leaf abscission is comparatively low. However, it is unclear what affect yearly coronatine-induced defoliation events and reduced chlorophyll content would have on long-term tree health and yield. Finally, impediments to coronatine production must be overcome. Yields of coronatine ranged from 20 to $25 \mathrm{mg} \cdot \mathrm{L}^{-1}$ fermentation media, and must be increased to conduct large-scale trials necessary to evaluate efficacy. Typically, $1 \mathrm{~g}$ coronatine was needed in $5 \mathrm{~L}$ total volume for application to a single tree. Efforts to improve yield of coronatine in the fermentation are underway and will allow us to evaluate the full potential of coronatine as an abscission material for citrus.

\section{Literature Cited}

Bender, C.L., F. Alarcón-Chaidez, and D.C. Gross. 1999. Pseudomonas syringae phytotoxins: Mode of action, regulation, and biosynthesis by peptide and polyketide synthetases. Microbiol. Mol. Biol. Rev. 63:266-292.

Benedetti, C.E., C.L. Costa, S.R. Turcinelli, and P. Arruda. 1998. Differential expression of a novel gene in response to coronatine, methyl jasmonate, and wounding in the Coil mutant of Arabidopsis. Plant Physiol. 116:1037-1042.

Biesgen C. and E.W. Weiler. 1999. Structure and regulation of $O P R 1$ and $O P R 2$, two closely related genes encoding 12-oxophytodienoic acid10,11-reductases from Arabidopsis thaliana. Planta 208:155-165.

Burns, J.K. 2002. Using molecular biology tools to identify abscission materials for citrus. HortScience 37:459-464.

Burns, J.K., U. Hartmond, and W.J. Kender. 1999. Acetolactate synthase inhibitors increase ethylene production and cause fruit drop in citrus. HortScience 34:908-910.

Burns, J.K., D.J.Lewandowski, C.J. Nairn, and G.E. Brown. 1998. Endo1,4- $\beta$-glucanase gene expression and cell wall hydrolase activities during abscission in Valencia orange. Physiol. Plant. 102:217-225.

Falkenstein, E., B. Groth, A. Mithöfer, and E.W. Weiler. 1991. Methyljasmonate and $\alpha$-linolenic acid are potent inducers of tendril coiling. Planta 185:316-322.

Fan, X., J.P. Mattheis, and J.K. Fellman. 1998. A role for jasmonates in climacteric fruit ripening. Planta 204:444-449.

Ferguson, I.B. and R.E. Mitchell. 1985. Stimulation of ethylene production in bean leaf discs by the pseudomonad phytotoxin coronatine. Plant Physiol. 77:969-973.

Gnanamanickam, S.S., A.N. Starratt, and W.B. Ward. 1982. Coronatine production in vitro and in vivo and its relation to symptom development in bacterial blight of soybean. Canadian J. Botany 60:645-650.

Haider, G., T. von Shrader, M. Füßlein, S. Blechert, and T.M. Kutchan. 2000. Structure-activity relationships of synthetic analogs of jasmonic acid and coronatine on induction of benzo[c]phenanthridine alkaloid accumulation in Eschscholia californica cell cultures. Biol. Chem. 381:741-748.

Hartmond, U., R. Yuan, J.K. Burns, A. Grant, and W.J. Kender. 2000a.
Citrus fruit abscission induced by methyl jasmonate. J. Amer. Soc. Hort. Sci. 125:547-552.

Hartmond, U., J.D. Whitney, J.K. Burns, and W.J. Kender. 2000b. Seasonal variation in the response of 'Valencia' orange to two abscission compounds. HortScience 35:226-229.

Hipkins, M.F. and N.R. Baker. 1986. Spectroscopy. In: M.F. Hipkins and N.R. Baker (eds.). Photosynthesis energy transduction. A practical approach. IRL Press, Eynsham, England.

Keane, P.J., A. Kerr, and P.B. New. 1970. Crown gall of stone fruit. II. Identification and nomenclature of Agrobacterium isolates. Australian J. Biolog. Sci. 23:585-595.

Kender, W.J., U. Hartmond, J.K. Burns, R. Yuan, and L. Pozo. 2001. Methyl jasmonate and CMN-pyrazole applied alone and in combination can cause mature orange abscission. Sci. Hort. 88:107-120.

Kenyon, J.S. and J.G.Turner. 1992. The stimulation of ethylene synthesis in Nicotiana tabacum leaves by the phytotoxin coronatine. Plant Physiol. 100:219-224.

Koch, T., T. Krumm, V. Jung, J. Engelberth, and W. Boland. 1999. Differential induction of plant volatile biosynthesis in the lima bean by early and late intermediates of the octadecanoid-signaling pathway. Plant Physiol. 121:153-162.

Koda, Y., K. Takahashi, Y. Kikuta, F. Greulich, H. Toshima, and AIchihara. 1996. Similarities of the biological activities of coronatine and coronafacic acid to those of jasmonic acid. Phytochemistry 41:93-96.

Kramell R., O. Miersch, R. Atzorn, B. Parthier, and C. Wasternack. 2000. Octadecanoid-derived alteration of gene expression and the "oxylipin signature" in stressed barley leaves. Implications for different signaling pathways. Plant Physiol. 123:177-187.

Mitchell, R.E. 1982. Coronatine production by some phytopathogenic pseudomonads. Physiol. Plant Pathol. 20:83-89.

Mitchell, R.E. and H. Young. 1978. Identification of a chlorosis-inducing toxin of Pseudomonas glycinea as coronatine. Phytochemistry 17: 2028-2029.

Miyamoto, K., M. Oka, and J.Ueda. 1997. Update on the possible mode of action of the jasmonates: Focus on the metabolism of cell wall polysaccharides in relation to growth and development. Physiol. Plant. 100:631-638.

Palmer, D.A. and C.L. Bender. 1993. Effects of environmental and nutritional factors on production of the polyketide phytotoxin coronatine by Pseudomonas syringae pv. glycinea. Appl. Environ. Microbiol. 59: 1619-1626.

Palmer, D.A. and C.L. Bender. 1995. Ultrastructure of tomato leaf tissue treated with the Pseudomonad phytotoxin coronatine and comparison with methyl jasmonate. Mol. Plant-Microbe Interact. 8:683-692.

Parchmann, S., H. Gundlach, and M.J. Mueller. 1997. Induction of 12oxo-phytodienoic acid in wounded plants and elicited plant cultures. Plant Physiol. 115:1057-1064.

Penninckx, I.A.M.A., B.P.H.J. Thomma, A. Buchala, J.-P. Métraux, and W.F. Broekaert. 1998. Concomitant activation of jasmonate and ethylene response pathways is required for induction of a plant defensin gene in arabidopsis. Plant Cell 10:2103-2113.

Perner, B., H.P. Schmauder, J. Müller, F. Greulich, and F. Bublitz. 1994. Effect of coronatine on ethylene release and ATPase activity of tomato cell cultures. J. Phytopathol. 142:27-36.

Rickauer, M., W. Brodschelm, A. Bottin, C. Véronési, H. Grimal, and M.T. Esquerré-Tugayé. 1997. The jasmonate pathway is involved differentially in the regulation of different defense responses in tobacco cells. Planta 202:155-162.

Schaller, F., C. Biesgen, C. Müssig, T. Altmann, and E.W. Weiler. 2000. 12-Oxophytodienoate reductase 3 (OPR3) is the isoenzyme involved in jasmonate biosynthesis. Planta 210:979-984.

Stelmach, B.A., A. Müller, P. Hennig, D. Laudert, L. Andert, and E.W. Weiler. 1998. Quantitation of the octadecanoid 12-oxo-phytodienoic acid, as signalling compound in plant mechanotransduction. Phytochemistry 47:539-546.

Stelmach, B.A., A. Müller, and E.W. Weiler. 1999. 12-Oxo-phytodienoic acid and indole-3-acetic acid in jasmonic acid-treated tendrils of Bryonia dioica. Phytochemistry 51:187-192. 
Toshima, H., Y, Niwayama, H. Nagata, F. Greulich, and A. Ichihara. 1993. Inhibitory effect of coronamic acid derivatives on senescence in cut carnation flowers. Biosci. Biotechnol. Biochem. 57:1394-1395.

Tsuchiya, T., H. Ohta, K. Okawa, A. Iwamatsu, J. Simada, T. Masuda, and K. Takamiya. 1999. Cloning of chlorophyllase, the key enzyme in chlorophyll degredation: finding of a lipase motif and the induction by methyl jasmonate. Proc. Natl. Acad. Sci. 96:15362-15367.

Ueda, J., K. Miyamoto, and M. Hashimoto. 1996. Jasmonates promote abscission in bean petiole explants: Its relationship to the metabolism of cell wall polysaccharides and cellulase activity. J. Plant Growth Regul. 15:189-195.

Ullrich, M., A.C. Guenzi, R.E. Mitchell, and C.L. Bender. 1994. Cloning and expression of genes required for coronamic acid (2-ethyl-1-aminocyclopropane 1-carboxylic acid), an intermediate in the biosynthesis of the phytotoxin coronatine. Appl. Environ. Microbiol. 60:2890-2897.

Völksch, B. and H. Weingart. 1998. Toxin production by pathovars of
Pseudomonas syringae and their antagonistic activities against epiphytic microorganisms. J. Basic Microbiol. 38:135-145.

Weiler, E.W., T.M. Kutchan, T. Gorba, W. Brodschelm, U. Niesel, and F. Bublitz. 1994. The Pseudomonas phytotoxin coronatine mimics octadecanoid signaling molecules of higher plants. FEBS Letters 345:9-13.

Wilson, W.C. 1973. Problems encountered using cycloheximide to produce abscission of oranges. HortScience 8:323-324.

Young, S.A., S.K. Park, C. Rodgers, R.E. Mitchell, and C.L. Bender. 1992. Physical and functional characterization of the gene cluster encoding the polyketide phytotoxin coronatine in Pseudomonas syringae pv. glycinea. J. Bacteriol. 174:1837-1843.

Zhao, Y.F., W.T. Jones, P. Sutherland, D.A. Palmer, R.E. Mitchell, P.H.S. Reynolds, J.P. Damicone, and C.L. Bender. 2001. Detection of the phytotoxin coronatine by ELISA and localization in infected plant tissue. Physiol. Mol. Plant Pathol. 58:247-258. 